\title{
Changes in atherosclerotic plaque composition assessed by MRI in the superficial femoral artery with two years of lipid lowering therapy
}

Amy M West ${ }^{*}$ AJ Pesch, Neesurg Mehta, Justin D Anderson, Frederick H Epstein, Craig H Meyer, Klaus D Hagspiel, Stuart S Berr, Nancy L Harthun, Jennifer R Hunter, Joseph M DiMaria, John M Christopher, Christopher M Kramer

From 2011 SCMR/Euro CMR Joint Scientific Sessions

Nice, France. 3-6 February 2011

\section{Objective}

We hypothesized that changes in atherosclerotic plaque composition with lipid lowering therapy could be measured in patients with peripheral arterial disease (PAD) using MRI of the superficial femoral artery (SFA).

\section{Background}

MRI of atherosclerotic plaque components in the carotid arteries correlates with histology, is reproducible, and can monitor lipid lowering therapy.

\section{Methods}

43 patients with PAD (age $63 \pm 9$, ABI $0.72 \pm 0.14$ ) were imaged at baseline and annually for 2 years after beginning lipid lowering therapy. Twenty statin-naïve patients were randomized to simvastatin $(\mathrm{S}, \mathrm{n}=11)$ or simvastatin +ezetimibe $(S+E, n=9)$. Patients already on statins not at LDL cholesterol goal had open-label ezetimibe added $(\mathrm{E}, \mathrm{n}=23)$. MRI of a single slice of the SFA was performed on Siemens Avanto 1.5T scanner with a proton-density weighted image (TR $1100 \mathrm{~ms}$, TE $7.6 \mathrm{~ms}$ ), T1-W image (TR 700ms, TE 7.7ms) and T2-W image (TR 2000ms, TE $85 \mathrm{~ms})$, using slice thickness $3 \mathrm{~mm}$, matrix 256x256 pixels, FOV $150 \mathrm{~mm}$, flip angle $180^{\circ}$. Image location was repeated over time using the distance of the imaged slice from the bifurcation of the common femoral artery. Image quality scale from 1-4 was used to grade the images, excluding 6 studies for score $\leq 2$ in more than one image. VesselMASS software was used to measure plaque components (lipids, calcium, loose matrix and fibrous tissue) based on published critieria for appearance on $\mathrm{T} 1 / \mathrm{T} 2 / \mathrm{PDW}$ images. Changes in parameters were

University of Virginia, Charlottesville, VA, USA assessed with ANOVA repeated measures model and correlation with two-tailed Pearson.

\section{Results}

LDL at baseline in the statin-naive patients $(\mathrm{S}$ and $\mathrm{S}+\mathrm{E})$ was $127 \pm 34 \mathrm{mg} / \mathrm{dl}$ and fell at one year $(82 \pm 37, \mathrm{p}<0.001)$ and was unchanged at two years $(84 \pm 44)$. There was no difference in LDL between S and S+E. The LDL in E at baseline was $93 \pm 21 \mathrm{mg} / \mathrm{dl}$, decreased significantly at one year $(77 \pm 35, \mathrm{p}<0.001)$, and was similar at year $2(74$ \pm 27 ). Total cholesterol changes paralleled that of LDL. See Table 1 for changes in wall area and plaque components. The amount of plaque lipids correlated with wall area $(r=0.44, p<0.003)$ for for all studies. Intra-observer

Table 1 Changes in plaque over time

\begin{tabular}{llll}
\hline & Baseline & Year 1 & Year 2 \\
\hline Wall Area $\left(\mathbf{c m}^{\mathbf{2}}\right)$ & & & \\
$\mathrm{S}$ and $\mathrm{S}+\mathrm{E}$ & $0.33 \pm 0.14$ & $0.32 \pm 0.14$ & $0.32 \pm 0.14$ \\
$\mathrm{E}$ & $0.31 \pm 0.05$ & $0.29 \pm 0.12$ & $0.29 \pm 0.12$ \\
Lipids $\left(\mathbf{c m}^{2}\right)$ & & & \\
$\mathrm{S}$ and $\mathrm{S}+\mathrm{E}$ & $0.05 \pm 0.04$ & $0.04 \pm 0.04$ & $0.03 \pm 0.03^{*}$ \\
$\mathrm{E}$ & $0.04 \pm 0.05$ & $0.04 \pm 0.05$ & $0.02 \pm 0.03^{*}$ \\
Calcium $\left(\mathbf{c m}^{2}\right)$ & & & \\
S and S+E & $0.004 \pm 0.007$ & $0.005 \pm 0.010$ & $0.009 \pm 0.016$ \\
$\mathrm{E}$ & $0.011 \pm 0.026$ & $0.011 \pm 0.022$ & $0.014 \pm 0.023$ \\
Loose Matrix $\left(\mathrm{cm}^{2}\right)$ & & & \\
S and S+E & $0.05 \pm 0.07$ & $0.04 \pm 0.05$ & $0.03 \pm 0.03$ \\
E & $0.03 \pm 0.06$ & $0.04 \pm 0.07$ & $0.04 \pm 0.07$ \\
Fibrous Tissue $\left(\mathbf{c m}^{2}\right)$ & & & \\
S and S+E & $0.23 \pm 0.13$ & $0.23 \pm 0.12$ & $0.25 \pm 0.13$ \\
E & $0.23 \pm 0.09$ & $0.20 \pm 0.10$ & $0.22 \pm 0.10$ \\
\hline
\end{tabular}

*ANOVA $p<0.05$.

(c) 2011 West et al; licensee BioMed Central Ltd. This is an open access article distributed under the terms of the Creative Commons Attribution License (http://creativecommons.org/licenses/by/2.0), which permits unrestricted use, distribution, and reproduction in any medium, provided the original work is properly cited. 


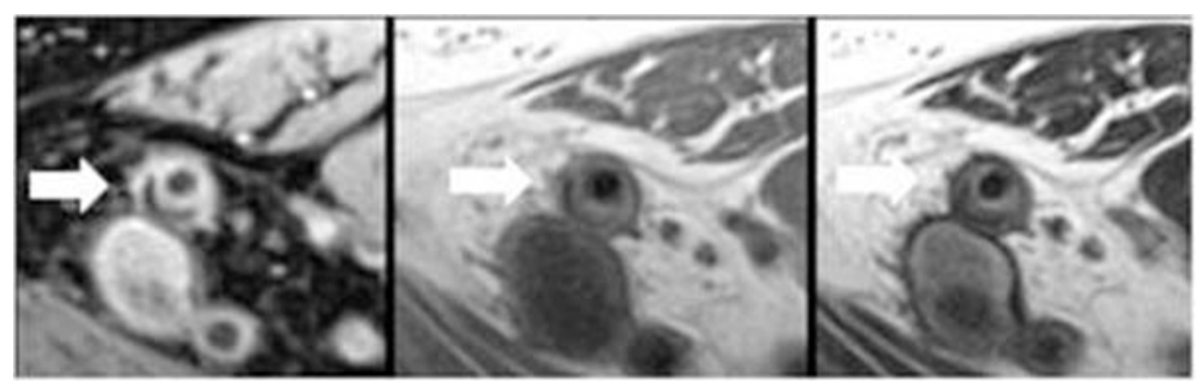

Figure 1 Representative PDW (left), T1-W (center) and T2-W (right) images of the SFA (arrow) in a study patient.

variability examined in 10 patients with an intra-class correlation coefficient of 0.99 for wall area and 0.88 for plaque components.

\section{Conclusion}

LDL lowering therapy over 2 years decreases plaque lipids without a significant change in plaque area or other components as demonstrated by MRI.

Published: 2 February 2011

doi:10.1186/1532-429X-13-S1-P382

Cite this article as: West et al: Changes in atherosclerotic plaque

composition assessed by MRI in the superficial femoral artery with two

years of lipid lowering therapy. Journal of Cardiovascular Magnetic

Resonance 2011 13(Suppl 1):P382.
Submit your next manuscript to BioMed Central and take full advantage of:

- Convenient online submission

- Thorough peer review

- No space constraints or color figure charges

- Immediate publication on acceptance

- Inclusion in PubMed, CAS, Scopus and Google Scholar

- Research which is freely available for redistribution

Submit your manuscript at www.biomedcentral.com/submit
C Biomed Central 